\title{
The Ohio Naturalist,
}

PUBLISHED BY

The Biological Club of the Ohio State Lniversity.

Volume XI.

JANUARY, 1911.

No. 3.

TABLE OF CONTENTS.

OsBors-Remarlis on the Genus Scaphoideus with Revised Key and Deseriptions

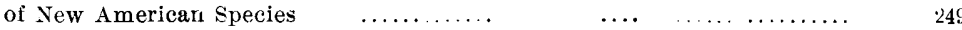

OsBorN-A New Species of Tinobregmus (Homoptera Jassidae) ............... 261

GRIGGS-Phlox Stolonifera Rediscovered in Ohio...................... 261

OsBorn-Some Reasons why a Natural History Survey is Needed in Ohio......... 263

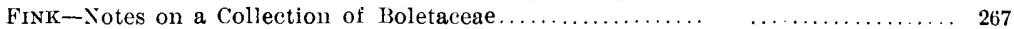

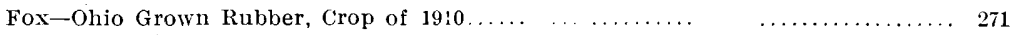

DickEY-Meeting of the Biological Club......... $\ldots \ldots \ldots \ldots \ldots \ldots \ldots \ldots, 272$

\section{REMARKS ON THE GENUS SCAPHOIDEUS WITH A REVISED KEY AND DESCRIPTIONS OF NEW AMERICAN SPECIES.}

\author{
Herbert Osborn.
}

Since the publication of my paper on this genus in $1900^{*}$ there have been a number of other species described, and I have secured records of distribution which considerably increase the range for a number of the older species, and moreover have recently obtained material which adds to these records, so that it appears to be an appropriate time to review the work presented in that paper.

At the time the paper was written the genus seemed to be quite strictly American and with the exception of a species described from the West Indies, St. Vincent Id., by Professor Uhler, the range of the genus being distinctly Nearctic. A species described from Japan, and more recently the description of two cther species from the Palearctic region shows that the genus has a wider range and would indicate for it a greater antiquity. Of the species which have been described as American since my previous paper on the genus, three are distinctly western, one distinctly eastern, and one southern or southeastern in range. Four species apparently new are described in the present paper.

But little has been added with reference to the life histories of the species, and in general the habits of the species are such that observations upon the life histories seem not to be very readily made. Considering the accessibility of my earlier paper it is deemed unnecessary to repeat descriptions or bibliography.

* The Genus Scaphoidcus, Jour. Cinc. Soc. Nat. Hist., Vol. XIX, pp. 187-209. (June, 1900.) 
No type species for the genus was indicated by Uhler and none so far as I know has been named since. I would therefore name immistus Say., the first species listed by Uhler in his paper describing the genus, and a distinctly representative species, as the type.

With some slight emendations the key presented in my former paper seems to possess the essential basis for the arrangement of the species, and in the revised key this arrangement has been followed in the main, simply making such additions and changes as permit of the inclusion of the other American species.

\section{Key to the Amerjcan Species.}

Lorae remote from the margin of the cheeks; common elytral picture cruciate; claval vein straight, meeting suture at acute angle.......

Lorae contiguous to or merging with border of cheeks: elytral picture not cruciate, outer claval vein curved or hooked at the distal end...2

1. Face yellow without cross bands ............................... Say

Face with two dark cross bands beside frontal arcs..............

3. Vertex short, very obtuse, size small, $4 \mathrm{~mm}$....... fasciatus Osb.

Vertex longer, rounded or sub-angular, size larger ............

4. Fore and middle femora yellow annulated with black... neglectus nsp

Fore and middle femora black, base and apex yellow...cruciatus nsp

2. Post nodal cell scarcely widened distally . . . . . . . . . . . . . . . 5

Post nodal cell much widened distally ...................... 6

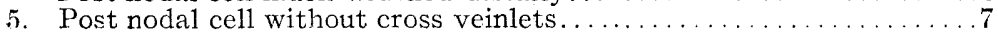

Post nodal cell with cross veinlets. . . . . . . . . . . . . . . . . .

7. Nodal vein arising from discal cell .......................

Nodal vein arising from anteapical cell ....................

9. Vertex flat with transverse impressed line . . . . . . . . . . . . . . . . 10

Vertex convex, no impressed line, edges rounded............... 11

10. Nodal vein from front of cell.................... jucundus Uh1.

Nodal vein from middle of cell. ................... fumidus Ball

11. Vertex wider than long, obtuse or rounded................... 12

Vertex as long or longer than wide, acute, scalaris V.D.-stigmosus Uhl.?

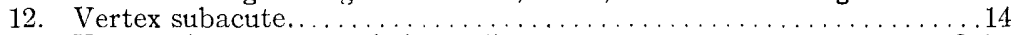

Vertex obtuse or rounded, small................ mexicanus Osb.

14. Nodal cell more than twice as long as wide. . . . . . . . . . . . . . . . . 16

Nodal cell but little longer than wide................ unicolor Osb.

16. Claval spots oval distinct......................

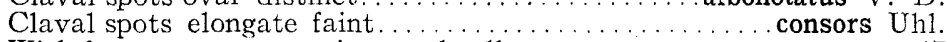

8. With few cross nervures in costal cell ....................

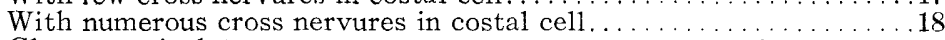

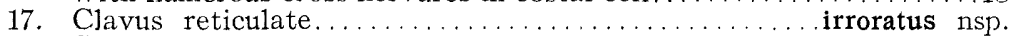

Clavus not reticulate...................... lobatus V. D.

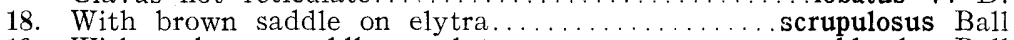

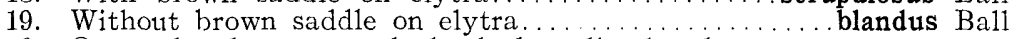

6. Outer claval not strongly hooked at distal end, cross nervure to

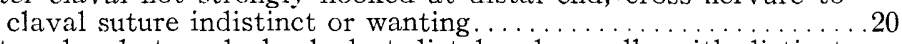

Outer claval strongly hooked at distal end, usually with distinct cross nervure from outer claval to claval suture ...........21

20. Outer claval sinuate approaching inner near its middle............. 22

Outer claval nearly straight and parallel to inner, curved at tip....23

22. Light ochreous, ultimate ventral segment truncate or slightly

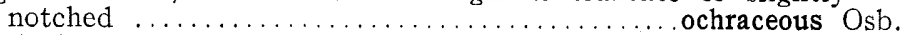
Marked with fuscous, ultimate ventral segment produced, productus Osb 
23. ㅇ ultimate ventral segment carinate, toothed at middle, carinatus Osb. o ultimate ventral segment not carinate, or toothed at middle....24

24. Head and pronotum ivory white or yellowish.......... intricatus Uhl. Head and pronotum with darker areas luteous or fulvus. .luteolus $V$. D.

6. No distinct cross veins between claval veins; colors gray or brown

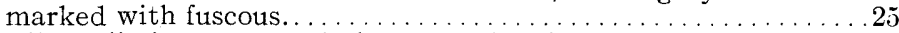

Usually a distinct cross vein between clavals . . . . . . . . . . . . 26

25. Face brown or light varied with darker markings......... immistus Say

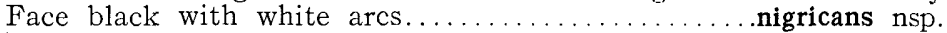

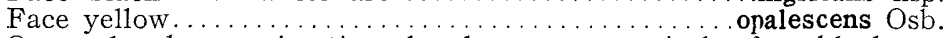

26. Outer claval approximating claval suture posteriorly; face black

melanotus Osb.

Outer claval remote from claval suture posteriorly ...........27

27. Vertex obtusely angulate; apex of elytra fuscous or black, obtusus Osb.

Vertex more produced, subacute; elytra entirely gray. . cinerosus Osb.

\section{Scaphoideus sanctus Say.}

Scaphoideus picturatus Osborn Proc. Ia. Acad. Sci. V, p. 243, (1898).

The original description for this species was based on specimens from Indiana, but no type specimens exist. The only species which has been secured from this region in recent years, agreeing with Say's description, is the one which I described under the name picturatus from material collected in Iowa and Kentucky.

Recent collections have shown this form to occur in Southern Ohio and at other points in the Ohio valley, but it has not been taken on the Atlantic slope nor in the Gulf States. Since the form hitherto known under the name sanctus, following Van Duzee's reference in 1894, has never been found in the Ohio valley nor outside of the Atlantic coast or Gulf States, there seems abundant reason to make the change suggested in my former paper and to recognize the Ohio valley form as sanctus. With this change the form occurring on the Gulf coast and which has the broad black band across the face remains undescribed. It resembles very closely the fasciatus described from Haiti, but as suggested by Van Duzee differs from that form in size and details of head, so that it seems best to recognize it as a distinct species. (See neglectus, poste.)

The sanctus of Say has a somewhat more pointed vertex, and the front is entirely without the black band which is so conspicuous in the other form. Say's statement "feet immaculate" applies better here than to the other form though there are black points on the tibia. The localities for this species will now stand as Indiana, (Say), Iowa (Osborn), Missouri, (Riley), Kentucky, (Garman), Illinois, Metropolis, "River," C. A. Hart, 3 females, 3 males, in I11. State Lab. Natural History, and Ohio, (Osborn), the localities in the latter state being Marietta and Portsmouth. Practically all of these records are based upon single specimens, which indicates a distinct rarity for the species. The specimen I took at Marietta was found on willows or vegetation close to them, but 
where there was too much mixture of various plants to warrant. the fixing of the host plant. For the other records no definite food plant has been given, so that we cannot assume to name the host species.

This form agrees closely with the others of the fasciatus group in the cruciate marking upon the dorsum, making with these forms a distinct subdivision of the genus. They differ somewhat from the other members, but in view of the venation and the head characters it seems hardly desirable to separate them from the genus.

\section{Scaphoideus fasciatus Osb.}

Jour. Cinc. Soc. N. H., Vol. XIX, p. 190.

This species described in 1900 from Port au Prince Haiti, has been recognized by Van Duzee from Florida and is probably best retained as a distinct species, although it is certainly closely related to the succeeding species described to cover the southern form hitherto known as sanctus. In this species the head is rather short, the points at the tip of the vertex minute, the transverse band on the face double and continued laterally on the pleurae, and the length is about four millimeters.

There is a specimen in the National Museum bearing a Ms. (apparently unpublished) name from Granada which agrees closely with this species. Van Duzee records are for Crescent City and St. Petersburg, Fla.

\section{Scaphoideus neglectus n. sp.}

Scaphoideus sanctus, Van Duzee. Tr. Am. Ent. Soc. Vol. XII, p. 300.

Closely resembles fasciatus and cruciatus, but is larger and with the vertex more angular than the former, smaller, with different markings on vertex, face, femora, and genital plates than the latter. Length four to four and one-half millimeters.

Vertex rounded, bluntly angular, about one and one-half times as long at center as next to the eye; the front broad at base, narrowing very $1 \mathrm{ni}$ formly and rapidly to the clypeus; clypeus widening slightly to the apex; lorae moderate, rounded, not reaching the border of the cheeks, the border of the cheeks slightly sinuate; pronotum strongly arched in front, truncate, or very slightly emarginate on hind border; elytra with the venation as in related species, the reflexed costal veins distinctly and about equally oblique.

Color, whitish ivory tinged with gray and marked with black and brown; the vertex with transverse black bands just in front of the middle, a pair of minute, almost obsolete, black points near the apex, and four black points on the hind border; the front with two black arcs next the vertex ard a black band from below the eyes across the front just beneath the antennae; the apical portion of lorae and clypeus and sub-margin of cheeks black or dark brown; the anterior femora black above, yellowish at base $c$ nd apex and beneath, middle femora yellow with a black annulus at the tip; hind femora yellow, hind tibiae yellow with black points; tarsi yellow arr vlated with black; pronotum ivory white in front, gray brown behind, with 
two or four black markings in a transverse line near the front. In the male the four oval black spots on the hinder half; scutullum with a black dot in the anterior angle; elytra similar to the related species with the basal part of corium ivory white; the oblique white mark on the apical portion of the clavus straight and scarcely inflated next the commissure; the ante-apical cells mostly brown with white dashes following the veins; apical cells, 1 partly white, the remainder black, 2 entirely black, 3 black apically whitish transparent for a large central spot, 4 semi-transparent in the central portion; beneath the venter white with black margins to the segments; base of pygofer black, and a black dash on the apical portion; ovipositor black, yellow at tip. In the male the valve is black and the plates with a sub-margin of blackish. There is also a central line of black spots on the venter.

Genitalia-Last ventral segment of the female short, nearly straight on hind border. pygofer rather long, equaling the ovipositor. The male valve small, distinctly rounded behind, the plates short, about one-half the length of the pygofer, broad, rounded on the border and at the tip minutely - ciliate; pygofer rather long and densely ciliate.

Described from five specimens-one female, Plano, Texas, a male and female labeled "Texas," one male, Clearwater, Fla., and one male, Frontera Tobasco, Mex. This last the one which was formerly referred to fasciatus Osb. I have also seen specimens as stated under sanctus in my previous paper, from Fla.in Van Duzee Collection, from "Texas" collected by Aaron and one from Jacksonville, Florida, from Mr. Heideman. Mr. Van Duzee records a female from Clearwater, and a male from $\mathrm{Ft}$. Myers.

\section{Scaphoideus cruciatus n. sp.}

Scaphoideus sanctus Say?? Osborn, 20th, Rep. State Entom., N. Y., 1904, p. $523(1905)$.

Closely resembling fasciatus but larger, with the vertex more produced, and genital plates of the male more distinctly rounded and longer. Length or $4.5 \mathrm{~mm}$.

Vertex rounded, slightly angular in front, little more than half as long at middle as between the eyes; the front broad, narrowing sharply to the clypeus; lorae short, coming far short of the margin; prothorax strongly curved in front, truncate behind; scutellum broad, deeply indented at the middle; elytra extending beyond the abdomen. The reflexed veins two in number, the first one strongly oblique, the second slightly oblique enclosing a rather short stigma.

Color, yellowish ivory white marked with fuscous and black; the vertex yellowish with two transverse brown spots just in front of the middle; two minute black dots in a faint brown splash near the hind border; the front with two black arcs close to the vertex; a distinct bar from lower border of eyes crossing below the antennae, and a broader black bar across the clypeus and enclosing lower half of the lorae and apex of clypeus and continued for coxae and pleurae; the upper half of lora yellow margined with black; beak yellow. The fore and middle femora black with yellow at base and apex; tibiae yellow, tarsi yellow banded with black; elytra with the common cruciate brown mark bordered distinctly with dark brown or black; the oblique white mark of clavus inflated at commissure. Anteapical cells brown bordered with black their veins white. First and second apical cells mostly black, third mostly transparent, veins white, together forming a semi-transparent spot at the inner angle.

Genitalia: Male valve short, broadly rounded behind; plates broad, short, about half as long as pygofer, rounded on the outer border, slightly angular, almost acuminate at tip, distinctly ciliate as is also the pygofer. 
One specimen, male of this form from Cold Spring Harbor, Long Island, from Mr. H. G. Barber. It has hitherto stood under the name Sanctus Say? from the reference in my catalogue of the Jassidae of N. Y., but as indicated under the preceding species, it cannot be the form described by Say.

It is quite close to neglectus from Florida and Texas but differs so distinctly in the width of bar on front, the absence of oval spots on the pronotum, color of femora, the elytral marking, and especially in shape, and marking of genital plates that it must be separated at least until intermediate forms are secured.

Scaphoideus auronitens. Prov.

This species has been found at a good many localities outside of the original habitat cited, and among these are Channel Lake, I1l., Cold Spring Harbor, L. I., Ohio Pyle, Pa., Crisp, Pa., Knoxville, Tenn., and Montcrest, N. C. In these different localities the species retains very closely its characteristic features, having very little tendency to variation. The larval stages were recognized and described in my report on the Jassidae of New York State, 1904.

\section{Scaphoideus jucundus Uhler.}

In the various records for this species it has been limited mainly to northern localities, Canada, New York, Iowa, and south to Washington, D. C., but I have seen specimens from Tryon, N. C., which were taken by Mr. Fiske, and Mr. Van Duzee records it for Estero, Florida. It may therefore be regarded as covering the eastern United States.

\section{Scaphoideus fumidus Ball.}

Canadian Entomologist, Vol. XXXIII, p. 8.

"This species resembles blandus in form and size; color rich testaceous brown, the margins of vertex and pronotum and apex of elytra. Length five millimeters; width $1.5 \mathrm{~mm}$." This species also was described from Colorado, and no other records are known to me.

Scaphoideus consors Uhler.

The additional material secured for this species seems to establish the point of its distinctness from scalaris, although it is possible to secure specimens that stand intermediately between the two species. This species is more distinctly eastern, the various records covering New York to Texas, and additional records show its occurrence at Ohio Pyle, Pa., and at Tryon, N. C., and Van Duzee records it for Crescent City, Fla. The form which was separated as variety unicolor in my previous paper seems to be sufficiently distinct to warrant its separation as a distinct species, no intermediate or connecting forms having been observed. 


\section{Scaphoideus unicolor Osb.}

Scaphoideus consors var. unicolor Osborn, Jour. Cinc. Soc. N. H., Vol. XIX, p. $196(1900)$.

This species, as indicated above, is now separated from consors, and the characters given in the description of it as a variety will stand as the specific characters. The essential features in its separation will be the structure of the genitalia, although the intensity of coloration appears to be a fairly constant character. The post nodal cell is short and bordered by heavy brown cross veins. No additional localities have been recorded, but I have specimens from Chester, Ga., Anacostia, D. C., Provincetown, Mass., Staten Id., N. Y., so that its distribution now includes the territory from Massachusetts to Georgia and Alabama.

\section{Scaphoideus mexicanus Osb.}

This species described from Orizaba, V. C., Mex., from specimens which I secured there in January, 1892, has not been noticed in any recent collections.

Scaphoideus scalaris Van Duzee.

The various records of this species include localities all the way from Ohio to California, and more recent records include New York. I have also a record for Ohio Pyle, Pa.

Scaphoideus albonotatus Van D.

Buffalo Soc. Nat. Hist., Vol. IX, p. 226 (1909).

This species described by Mr. Van Duzee from specimens collected at Estero, Fla., belongs to the scalaris group. It is closely allied to consors and unicolor, but larger and stouter than either and marked with three pairs of oval white spots along the commissure of the elytra. The length is $51 / 2$ millimeters. The distinct markings, especially the shape of the elytral spots, and length of post nodal cell, separate this certainly from unicolor. The species has not been taken outside of the type locality.

\section{Scaphoideus stigmosus Uhler.}

Proc. Zool. Soc., London, 1895, No. 6, p. 77.

This was described by Mr. Uhler in his report upon the Hemiptera Homoptera of the Island of St. Vincent. According to this description the species is related to scalaris. Uhler's description is in a somewhat inaccessible paper, and for the benefit of American students may be reproduced here, especially as I have not seen specimens of the species and cannot give a complete, description: 
"Pale fulvous; form similar to S. scalaris, Van Duz., but with a longer and wider head and antennae nearly as long as the wing-cover. Vertex a little longer than its width between the eyes, almost flat, very pale fulvous, with a series of brown dots around the anterior submargin and some less regular ones on the middle, occasionally with two or three ivory-white dots before the middle; front irregularly clouded with pale brown, bounded above by a slender dark brown line. Clypeus broad, bluntly rounded, marked with a brown subapical spot; the rostrum reaching to the middle coxae. Eyes with a dark brown band below. Antennae dark brown, paler at base. Pronotum triangularly sublunate, well advanced into the deeply sinuated vertex, the surface minutely scabrous, transversely wrinkled, polished, dotted with pale yellow anteriorly, and minutely speckled with the same color behind the middle; the posterior angles subacute, a little produced, the posterior margin slightly sinuated. Scutellum with a dark brown spot in the basal angles; the disk a little marbled with brown. Wing-covers marked with three brown spots on the inner margin of the clavus, each of which has an acute white spot at the tip; veins white interrupted with brown, margins pale; the costal margin has a series of broader white streaks adjoining it inwardly, four large apical cells pale at base, bounded by brown veins, the apex a little dusky; wings smoky, with dark brown veins. Beneath and legs pale yellow, the tibiae somewhat marked with brown; the tarsal joints, nails, and spots at origin of the tibial spines dark brown; the spines pale brown. Last ventral segment of the female deeply notched, the valves of ovipositor set with long, brown, stiff bristles; tergum blackish, with pale edges to the segments and a pale tip.

"Length to end of venter $31 / 4 \mathrm{~mm}$., to tip of wing-covers $5 \mathrm{~mm}$.; width of pronotum, $1 \mathrm{~mm}$.

"Five specimens, all females, were secured on the island. One was taken at an altitude of 1500 feet above the sea, and two were collected at Kingstown."

\section{Scaphoideus lobatus Van D.}

This rather rare species described by Van Duzce from New York has been taken in Ohio at Milan, and I have seen specimens from Balsam, N. C., Madison, N. J., Cold Spring Harbor, L. I., and it has been reported in Iowa, so that it may be considered as occupying the northern part of the United States, extending south on the elevated Appalachian region. Nothing has been added concerning its life history

\section{Scaphoideus blandus Ball.}

Canadian Entomologist, Vol. XXXIII, p. 7.

This species described by Professor Ball in 1901 has the general appearance of jucundus; but is smaller and duller looking, the reddish tinge of that species being lacking. The costal margin of elytra with numerous regular cells. Length five millimeters; width 1.1 millimeters. This species was described from various localities in Colorado, and has not been recorded from any other region. 


\title{
Scaphoideus scrupulosus Ball.
}

\author{
Canadian Entomologist, Vol. XXXIV, p. 14.
}

This species is somewhat out of place in the genus Scaphoideus, but can not readily be referred to any other genus. The head characters agree distinctly, but in the appearance of wings and other features it is more like that of Eutettix. In the description by Professor Ball he says it is similar to blandus and jucundus in form, the elytra more flaring, and with the general appearance of Eutettix, except for the sharply angled vertex, a brown band on the base of the elytra, another on tip, and a triangular saddle on the disc. Length five millimeters; width 1.25 millimeters. Professor Ball's specimens were from Los Angeles, Cal., and I have one specimen from Sonoma Co., California, so that the species appears to be limited to that region.

\section{Scaphoideus irroratus n. sp.}

Somewhat resembles scrupulosus, but more distinctly irrorate and with the female ventral segment without any median appendage. Length $\& 5 \mathrm{~mm}$.

Vertex distinctly angular, nearly twice as long at center as next the eyes; the front rather broad, narrowing but little to the clypeus; the clypeus narrowing at base, widening slightly to the tip; the lorae rather large, oval, approaching the border; cheek distinctly sinuate under the eye; pronotum short, distinctly arched in front, slightly emarginate behind; elytra with numerous veinlets.

Color, fulvus and brownish, distinctly irrorate with fuscus on the pronotum and elytra; vertex tawny with indefinite transverse brownish irrorations; face without spots but with front suffused with fulvus; pronotum and scutellum about equally marked with brownish irrorations; the elytra with the irroration following the transverse veinlets and brown spots massing so as to form a rather indefinite saddle in front of the middle, and a transverse broad band on the apical third, leaving a rather clear space crossing the apex of clavus and reaching the costa; the costal cell with about three transverse veinlets; the post nodal cell with about six transverse veinlets bordered with fuscus; beneath brownish, tibiae and tarsi spotted with black.

Genitalia, last ventral segment of the female longer than the preceding and very slightly produced at center; ovipositor reaching the tip of pygofer; pygofer with short cilia next the border.

Described from a single female specimen from the University of California campus, Berkeley, from the Department of Entomology of the University of California. This species, while somewhat resembling scrupulosus and differing from typical Scaphoideus, presents the head characters of the genus, although the antennae are shorter than is the general rule with the genus. 


\section{Scaphoideus intricatus Uhl.}

Additional records for this species have been secured for Columbus, Ohio, taken on clover in September, 1909; at Akron on Cornus, September, 1909, and a record from Professor H. Garman for Lexington, Ky., September 20, 1909, on cultivated grape, also from Franconia, N. H., by Mrs. Slosson. The original description referred this species to Crataegus, but it has been taken on so many different plants and in some cases so remote from this tree that it is uncertain as to its normal food plant. So far as I know the larvae have not been seen, and consequently the food habit as determined by the larvae is uncertain. The species is now known to range from Kansas and Nebraska to New Hampshire and south to Virginia and Kentucky.

\section{Scaphoideus ochraceus Osb.}

Further records showing distribution of this species have been secured since the publication of my paper in 1900, for Durham, N. H., Buffalo, N. Y., 1907, and Ohio Pyle, Pa., Aug. 10, 1905. It must undoubtedly occur in Ohio, but so far has not appeared in collections.

\section{Scaphoideus productus Osb.}

This species has been recognized at various localities, especially to the south. I have records for Balsam, N. C., at altitudes of 4500 to 5000 feet, from the Department of Agriculture of North Carolina, and have also seen specimens collected at Tryon, N. C., by Mr. Fiske. Mr. Barbour has sent me a specimen from Cold Spring Harbor, L. I., so the species is pretty well distributed from Onaga, Kansas, Sioux City, Ia., east through Kentucky into North Carolina, and north to New York.

\section{Scaphoideus carinatus Osb.}

This species has been recorded from Cold Spring Harbor, L. I., (Barbour) and Black Mt. (Beutenmueller) Tryon, N. C. (at light) from Fiske, Little Mt., Ohio, in addition to the previous records. So far no specimens have been obtained from western localities, so that it appears to belong to the Atlantic region from New Hampshire to North Carolina, and west to eastern Ohio at least.

\section{Scaphoideus nigricans $\mathrm{n}$. sp.}

Closely related to immistus, but much darker and with the female genital segment longer, and with a polished produced hinder border. Length $5.5 \mathrm{~mm}$.

Vertex about twice as long at middle as next the eye, rounding to a distinct obtuse angle at the tip; front rather narrow, sloping uniformly to the clypeus which is distinctly widened apically; lorae large, touching the border of the cheek; pronotum distinctly emarginate behind; elytra trans- 
lucent, the claval veins approaching each other near the center, but without any distinct cross vein; the reflexed venis three, first ante-apical not stylate.

Color, dark brown, mostly black beneath; vertex dark brown with light areas at the sides in the anterior half; face black with four white arcs on the upper half of the front; pronotum dark brown, two white spots on the anterior border; scutellum with four white points on the base, one at apex, and one each side midway from apex to base; elytral markings as in immistus, but darker; beneath black except median and lateral line on the venter, the basal part of the last ventral segment white the lower part of femora and the tibiae whitish; tarsi annulated with white.

Genitalia, Last ventral segment of the female long, produced and slightly notched on the posterior border, distinctly polished; ovipositor and pygofer dark brown with a whitish band near the tip.

Described from a single specimen from Raleigh, N. C., taken in late May by Mr. Z. P. Metcalf, to whom I am indebted for the opportunity to describe it.

\section{Scaphoideus immistus Say.}

This species which stands as the type of the genus, was described by Say among the earlier descriptions of American insects, and was doubtless abundant at that time as it has been since. It is one of the most common species met with in many parts of the country, and its distribution is very extensive, specimens having been taken all the way from the Atlantic to the Pacific coasts. It is especially abundant in the Mississippi Valley and seems to occur on quite a variety of plants. Notwithstanding its abundance its life history and the food plants of the larval stages have not been determined, a fact which makes it difficult to assign any definite limitations to the numerous varieties of the species.

The species is one of the most variable in the genus, and some of the more definite of these varieties were described in my paper of 1900 , but as stated in that paper, there are many other variations which defy description because of the insensible gradations represented between the different forms.

\section{Scaphoideus luteolus Van D.}

This species is pretty closely related to immistus, the characters for its separation being indefinite, but depending mainly on the characters of the claval veins and the male genitalia. The distribution has not been modified by recent collections and no further information regarding the life history has been secured.

Scaphoideus cinerosus Osb.

No further data have been secured regarding this species.

Scaphoideus melanotus Osb.

This species which appears to have been very rare and which has been known hitherto only from the specimens in hand at the time of the original description, two of which were from Texas and one 
from Maryland, has recently been sent to me from Pennsylvania in some material submitted by the Carnegie Museum. This specimen agrees perfectly with the type material, so that it strengthens the impression as to the distinctness of the species. The most evident character is the intensely black face.

\section{Scaphoideus opalinus Osb.}

\section{0th Report N. Y. State Entomologist, 1904, p. (1905).}

This species was described from specimens taken in 1904 at Cold Spring Harbor, L. I., on red cedar, and it has been reported later from Riverton, N. J., Gowanda, N. Y., and Seven Oaks, Fla., by Mr. E. P. Van Duzee. The specimens from these different localities agree so perfectly with the type material that the species may be considered as well defined, although, as stated in my original description, it stands close to immistus in the immistus group.

\section{Scaphoideus obtusus Osb.}

No further undoubted specimens of this species have appeared since the original description, but Mr. Van Duzee has collected at Crescent City, Sanford, Seven Oaks, and Fort Myers in Florida, specimens which he is inclined to refer to this species. They appear to me to be somewhat closer to typical immistus than the type specimens of obtusus and so might be considered as connecting the form with that species; however, Mr. Van Duzee has taken one specimen at Lancaster, N. Y., which agrees distinctly with the type material, and so far as these specimens go there is a fairly distinct separation from immistus.

\section{Scaphoideus festivus Mats.}

Termesz Fuget, 25, p. 384, f. 14.

This species described by Matsumuri for Japan has been recorded for other parts of the oriental region, Ceylon and British India, and is probably somewhat generally distributed in the oriental region.

The species corresponds pretty closely with our immistus which it is said by Matsumuri to closely resemble and occupies for the old world about the same position that immistus does with us.

Aside from the above species, two other species of the genus have been described from the old world

\section{Scaphoideus aegypticus Mats.}

Jour. Coll. Sc. Un. Tokyo, 23, No. 6, p. 291, f. 7 (vide Oshanin). The only locality cited is Egypt.

\section{Scaphoideus horvathi Mats.}

Jour. Coll. Sc. Un. Tokyo, 23, No. 6, p. 29, t1 f 7 (vide Oshanin).

Described from Algeria. 